\title{
年齢階級別にみた高齢者の食習慣
}

\author{
佐 藤 紀代美 \\ (大阪薰英女子短期大学)
}

\section{Study on Dietary Habits by Age Group among Elderly Persons}

\author{
Kiyomi Satoh
}

Osaka Kun-ei Women's Junior College, 1 - 4 - 1, Shojaku, Settsu - shi, Osaka, 566 - 8501

$$
\text { 厂566-8501 大阪府摂津市正雀 } 1-4-1
$$

A study on dietaty habits by age group was conducted among 78 elderly persons aged 65 or older living in Kinki area or Okayama Prefecture. The subjects were divided into four groups; a group of $65-69$ years, a group of $70-74$ years, a group of $75-79$ years and a group of 80 years and older. The purpose of this study was to examine the characters of present dietary habits considering the effect of childhood and youth diet on present elderly dietary habits.

The results obtained were as follows:

(a group of 65-69 years) The subjects tended to show lower frequency for eating meats though they were youngest in all the groups.

(a group of 70-74 years) There was nothing characteristic about the persent dietary habits in this age group.

(a group of $75-79$ years) The subjects tended to decrease in the intake of food items of animal origin. Intake of meats among men and intake of milk among men and women were noticeably insufficient. These tendencies were considered to be influenced by the unbalanced diet in childhood and youth.

(a group of 80 years and older) The subjects tended to increase in the intake of food items of animal origin though they were oldest in all the groups. This tendency was considered to be influenced by the diet comparatively sufficient in quantity in childhood and youth. In this group, intake of bread was higher than in other age groups and intake of Miso - bean soup was noticeably insufficient.

The subjects in all the age groups tended not to retain some of uniquely japanese dietary habits such eating steamed rice as staples. The food that the subjects in all the age groups took habitually to maintain their health was milk. As for the awareness of daily habits, there were differences according to sex, but not age. 


\section{1. 緒 言}

人口の高齢化が進む近年, 高路者を対象とした様々な 食事調査が行われている. しかし，その調査結果の大半 は横断研究により分析, 報告されるために, 年歯階級別 の差を直接加齢変化として捉える危険性を秘めている11). また，筆者は高齢者の現在の食習慣は過去の食生活の影 響を少なからず受けているものと考えた。そこで本調査 では, 65 歳以上の高齢者の現在の食習慣の特徵について, 「遠い過去の食事の思い出し2)」によって得られた過去 の食生活の内容と照らし合わせて検討することを目的と した，調査を進める上で，昭和15～20年に起こった第二 次世界大戦を体験した時の年齢の差が過去の二つの時限 として設定した「子供の頃」抢よび「若い頃」の食生活 に大きな差をもたらしていることがわかった。したがっ て, 本調查では, 調査対象者を年齢階級別に分類するこ とを重要視し，4グループ（65～69歳， 70〜 74歳， 75〜 79 歳, 80 歳以上）各々の食習慣について考察することと した.

\section{2. 調查方法}

\section{（1）調査対象者および調査時期}

近畿圈（主に京都市内）および岡山県下（主に倉敷市 内）に在住する, 痴呆の症状の認められない健康な65歳 以上（最高年歯：93歳）の男性 18 人, 女性 60 人, 計 78 人 を対象として，1999年 $7 〜 8$ 月に食生活に関する調查を 行った.

回収率は $100 \%$ であった。

\section{(2) 調查方法}

調査方法は郵送法とし, 調查用紙と共に本調査用紙と 全く同じものに記入例を示したものを一部同封した。こ れは，対象者が記入方法や質問の意味を理解できないた めに起こり得る, 部分的な無回答や不適当な回答を最小 限に留める目的で行った.

\section{(3) 調査内容}

対象者の健康度，「子供の頃」と「若い頃」と「現在」 の食生活, および現在の食習慣と生活習慣についての調 査を行った.

\section{(4) 集計方法}

集計は主に性別, 年歯階級別（65～69歳， $70 ７ 4$ 歳, 75〜79歳, 80 歳以上の 4 グループ）に行った. なお, 食 習慣を意図的に变化させる可能性のある疾病に罹患した ことがある者（以下，「病歴ありの者」とする）につい ては，このことにより回答内容にバイアスが生じると考 えられる質問項目のみ集計より除外した. 対象者の性別, 年歯階級別における居住地域, 病歴ありの者, および独 居の内訳を表 1 に示した.

\section{3．調査結果および考察}

\section{（1）対象者の健康度}

本調査では, 食事調査法の中で困難であるとされてい る「遠い過去の食事の思い出し2)」を行ってもらうため に痴呆の症状の認められない, 心身の健康な高歯者を対 象としている. 対象者の抽出はその近親者の主観的な評 価のもとに行ったが，対象者の健康度を客観的に評価す る方法として老研式活動能力指標を用いた. 日常生活動 作能力 (ADL) や手段的日常生活動作能力 (IADL) が主 に生活機能の障害を有する高齢者の生活機能を評価する 指標として用いられているのに対して, 古谷野ら゙)によ って開発された老研式活動能力指標は, 一般の地域老人 の生活機能の正常老化を評価する指標であり, 健康度自 己評価との間に正の相関関係が認められるとされてい る.

表 2 に老研式活動能力指標の全文, 表 3 に日本の地域 老人の全国代表サンプルおよび本調査対象者の老研式活 動能力指標の得点分布を示した.

全国代表サンプルならびに本調査結果ともに年齢階級 が高くなるに従って老研式活動能力指標の得点の平均值

表 1 調査対象者の性別, 年齢階級別内訳

\begin{tabular}{|c|c|c|c|c|c|c|c|c|c|c|c|c|}
\hline & \multicolumn{6}{|c|}{ 男性 } & \multicolumn{6}{|c|}{ 女性 } \\
\hline & \multirow[b]{2}{*}{$\mathrm{n}$} & \multirow[b]{2}{*}{ 病歴ありの者 } & \multicolumn{2}{|c|}{ 居住地域 } & \multicolumn{2}{|c|}{ 独居 } & \multirow[b]{2}{*}{$\mathrm{n}$} & \multirow[b]{2}{*}{ 病歴ありの者 } & \multicolumn{2}{|c|}{ 居住地域 } & \multicolumn{2}{|c|}{ 独居 } \\
\hline & & & 近埌 1 & 岡注: 2 & $\mathrm{n}$ & $(\%)$ & & & 近 & 岡 & $\mathrm{n}$ & (\%) \\
\hline $65 \sim 69$ 歳 & 1 & 0 & 0 & 1 & 0 & 0 & 9 & 1 & 3 & 6 & 1 & 11.1 \\
\hline $70 \sim 74$ 歳 & 6 & 1 & 4 & 2 & 0 & 0 & 16 & 1 & 10 & 6 & 4 & 25.0 \\
\hline $75 \sim 79$ 歳 & 5 & 0 & 2 & 3 & 0 & 0 & 11 & 2 & 6 & 5 & 3 & 27.3 \\
\hline 80歲—80歳代 & 6 & 0 & 3 & 3 & 0 & 0 & 21 & 2 & 10 & 11 & 4 & 16.7 \\
\hline 以上-90歳代 & 0 & - & - & - & - & - & 3 & 0 & 1 & 2 & 0 & 0 \\
\hline 計 & 18 & 1 & 9 & 9 & 0 & 0 & 60 & 6 & 30 & 30 & 12 & \\
\hline
\end{tabular}

注 1 ) 近畿圏 注 2 ) 岡山県下 
毎日の生活についてうかがいます，以下の質問のそれぞれについて，「はい」「いいえ」のいずれかに○を つけて，お答え下さい，質問が多くなっていますが，ごめんどうでも全部の質問にお答えください．
(1) バスや電車を使って一人で外出できますか
はい いいえ
（2）日用品の買い物ができますか.....
（3）自分で食事の用意ができますか
(4) 請求書の支払いができますか
（5）銀行預金・郵便貯金の出し入れが自分でできますか
(6) 年金などの書類が書けますか
(7) 新聞を読んでいますか
(8) 本や雑誌を読んでいますか
（9）健康についての記事や番組に関心があり末すか
(10)友だちの家を訪ねることがありますか
(11) 家族や友だちの相談にのることがありますか
(12) 病人を見舞うことができますか
(13) 若い人に自分から話しかけることがありますか
はい いいえ
はい いいえ
はい いいえ
はい、いいえ
はい、いいえ
はい いいえ
はい いいえ
はい いいえ
はい いいえ
はいいいえ
はい いいえ
はい いいえ

注 :「はい」と回答した質問項目の数を数えて合計得点とする。

表 3 老研式活動能力指標の得点分布

\begin{tabular}{lrcccc}
\hline & \multicolumn{2}{c}{ 全国代表サンプル } & & \multicolumn{2}{c}{ 本調査対象者 } \\
\cline { 2 - 3 } & $\mathrm{M} \pm \mathrm{S} \mathrm{D}$ & $\mathrm{n}$ & & $\mathrm{M} \pm \mathrm{S} \mathrm{D}$ & $\mathrm{n}$ \\
\hline 65〜69歳 & $11.8 \pm 2.0$ & 668 & & $12.40 \pm 0.97$ & 10 \\
$70 \sim 74$ 歳 & $11.0 \pm 2.6$ & 537 & & $12.41 \pm 0.85$ & 22 \\
$75 \sim 79$ 歳 & $10.5 \pm 3.0$ & 345 & & $11.69 \pm 1.54$ & 16 \\
80歳以上 & $8.0 \pm 4.2$ & 259 & & $10.89 \pm 2.59$ & 30 \\
\hline
\end{tabular}

は低下し, 標準偏差は増大している.これは加龄に伴っ て生活機能が低下すること，また高龄になるほどその度 合には個人差があることを示している，調査の結果，得 点の平均值は全国代表サンプルと比較するといずれの年 齢階級においても高かった，65～69歳，70〜74歳，およ び75〜79歳のグループにおいては全国代表サンプルと比 較して著しく得点の低いものは見られなかった．得点の バラつきの大きい 80 歳以上のグループの最低点と最高点 は, $80 \sim 84$ 歳では 9 点と 13 点, 85 89歳では 6 点と 13 点, 90 歳代では 4 点と 13 点であり, 加齢に伴って最低点が著 しく低下した．本調査ではこれらの低い得点を持つ者に ついて, 近親者の評価も考慮した上で加㱓に伴う正常老 化の範囲とみなし本調査の対象者は全員健康であるとし た。

\section{（2）「子供の頃」と「若い頃」と「現在」の食生活 \\ 1）過去という時限の年齢設定}

「遠い過去の食事の思い出し」をしてもらう場合に， 予め過去のある年齢を明示する方法が考えられるが，本 調査では過去の二つの時期を漠然とした表現である「子 供の頃」と「若い頃」という形で示し, 回答者自身に各 々の時期の年齢を想像，設定してもらった。
表 4 過去の時限の年齢設定

\begin{tabular}{lcrr}
\hline & & 子供の頃 & \multicolumn{1}{c}{ 若い頃 } \\
\cline { 4 - 4 } & $\mathrm{M} \pm \mathrm{S} \mathrm{D}$ & $\mathrm{M} \pm \mathrm{S} \mathrm{D}$ \\
\hline $65 \sim 69$ 歳 & 10 & $10.10 \pm 1.79$ & $20.30 \pm 1.77$ \\
$70 \sim 74$ 歳 & 22 & $9.95 \pm 2.17$ & $20.90 \pm 3.33$ \\
$75 \sim 79$ 歳 & 16 & $10.86 \pm 3.86$ & $21.63 \pm 5.08$ \\
80 歳以上 & 30 & $9.23 \pm 2.24$ & $24.23 \pm 6.38$ \\
\hline
\end{tabular}

結果を表 4 に示した.

「子供の頃」として想像される年齢は, 各年歯階級間 にほとんど差は認められず, 平均して10歳前後であった. 一方「若い頃」として想像される年齢は, 年齢階級が高 くなるに連れて少しずつ高くなる傾向が見られ，本調査 では79歳以下の者は20歳位を，80歳以上の者は25歳位を 想像して回答していることがわかった.

\section{2）各年噛階級における過去の時代的背景}

図 1 に各年齢階級における「子供の頃」および「若い 頃」の年代と時代的背景を示した.

食生活に大きな変化をもたらした最も注目すべき歴史 的事項は，昭和15〜20年に起こった第二次世界大戦であ る. 食糧事情は大戦前の昭和14年頃から徐々に悪化し, 大戦中はもちろんのこと大戦直後の混乱期の数年間に至 るまで極度の食糧不足が続いた4)とされている。

\section{3）主食に見る「子供の頃」と「若い頃」と「現在」}

\section{の食生活}

図 1 より, 本調査対象者の「子供の頃」および「若い 頃」の時代は第二次世界大戦前から戦中, 戦後なでの時 期に当たることがわかった．第二次世界大戦前の日本に おける食事の典型は，主食である飯と副食である一汁一 


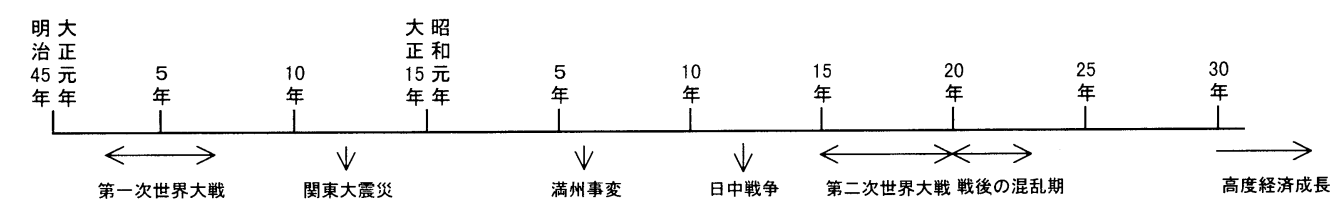

子供の頃

80 歳以上

若い頃

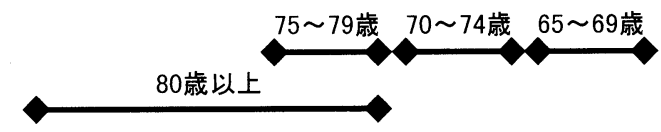

図 1 「子供の頃」および「若い頃」の年代と時代的背景

菜の組み合わせであり，副食は主として植物性食品であ ったがその種類は少なく，一日に必要なエネルギーやた くぱく質の摂取には主食である穀類に頼っていたと言わ れる ${ }^{5)}$. しかし, 大戦中や大戦直後の食の貧困な時代に おける食生活では主食を確保することすら困難であった と考えられる.

そこで筆者は第一に, 当時の食生活をその中心となっ ていた主食に注目して捉えることとし，各時代に食べて いた主食を自由に記述してもらった。

各年齢階級における「子供の頃」,「若い頃」, および 「現在」の主食の内容を表 5 に示した.

古代より日本人の主食は米であったが，常に不足して いる状況にあり，その不足分を補うためにヒエ，アワ， キビなどの雑穀や麦を混ぜた “かて飯”を食べるのが普 通であった. 大正時代に入ってからは，米には主として 麦が混ぜられ, 昭和初期に拈いては米食が最も多く, つ いで米麦食であった．このように，戦前までの日本人の 主食は米飯あるいは麦を混ぜた麦飯がほとんどであった が, 食糧事情の悪化とともに米のみの主食は激減し, 米 に混ぜる穀物の種類もこれまでの麦ではなく雑穀類が増
えた。 また, 少量の米でできる雑炊や粥，あるいは代用 食も主食にせざるを得なくなった ${ }^{5)}$.

本調査では, 食糧事情の悪化の象徵とも言える雑穀飯 (雑穀十米), 雑炊・粥, および代用食を主食とした者 の割合の合計（以下，総称して「雑穀飯等の割合」とす る）を比較, 検討することにより, 各年齡階級の食生活 を考察した。

65〜69歳：「子供の頃」は戦中に当たるが雑穀飯等の 割合は $0 \%$ であった。しかし，白米を主食とした割合が 著しく少なく，麦飯を主食とした割合が非常に多いこと より，恵まれた食生活であったとは言えないと考えられ る. 一方,「若い頃」は白米を主食とした割合が 8 割を 占めたが，これは食糧事情の好転期を経て高度経済成長 に向かう時代であったためであり, 食生活はかなり向上 したことがわかる。

70 74歳 :「子供の頃」の雑穀飯等の割合は $10 \%$ 未満 であり, 食生活は安定していたと考えられる.しかし,

「若い頃」における雑穀飯等の割合が $33.3 \%$ あること と当時の米不足を補うためと考えられるパンを主食とし た割合が多いことから, 戦後の混乱期と一致するこの頃

表 5 主食の内容

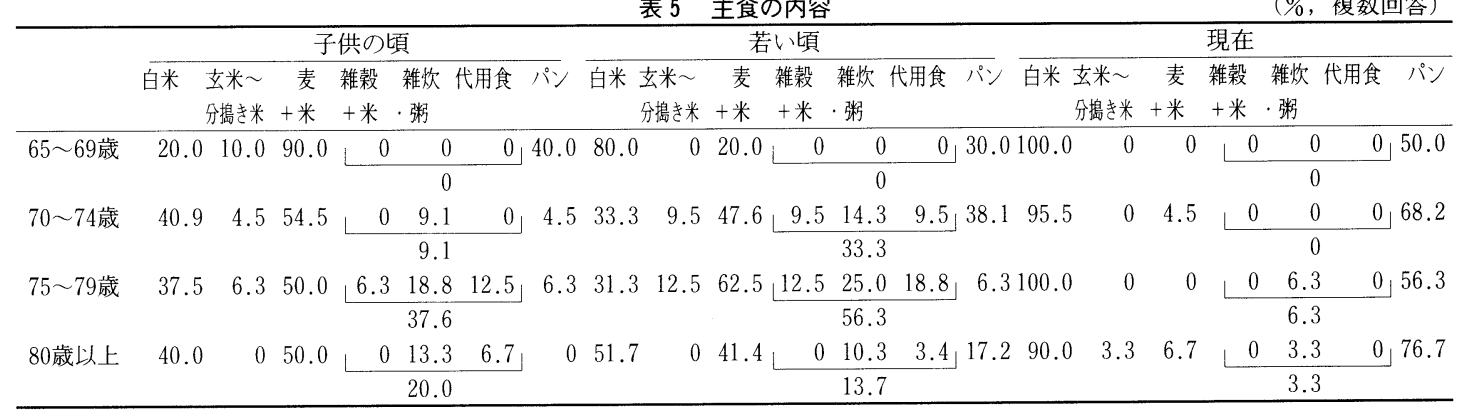



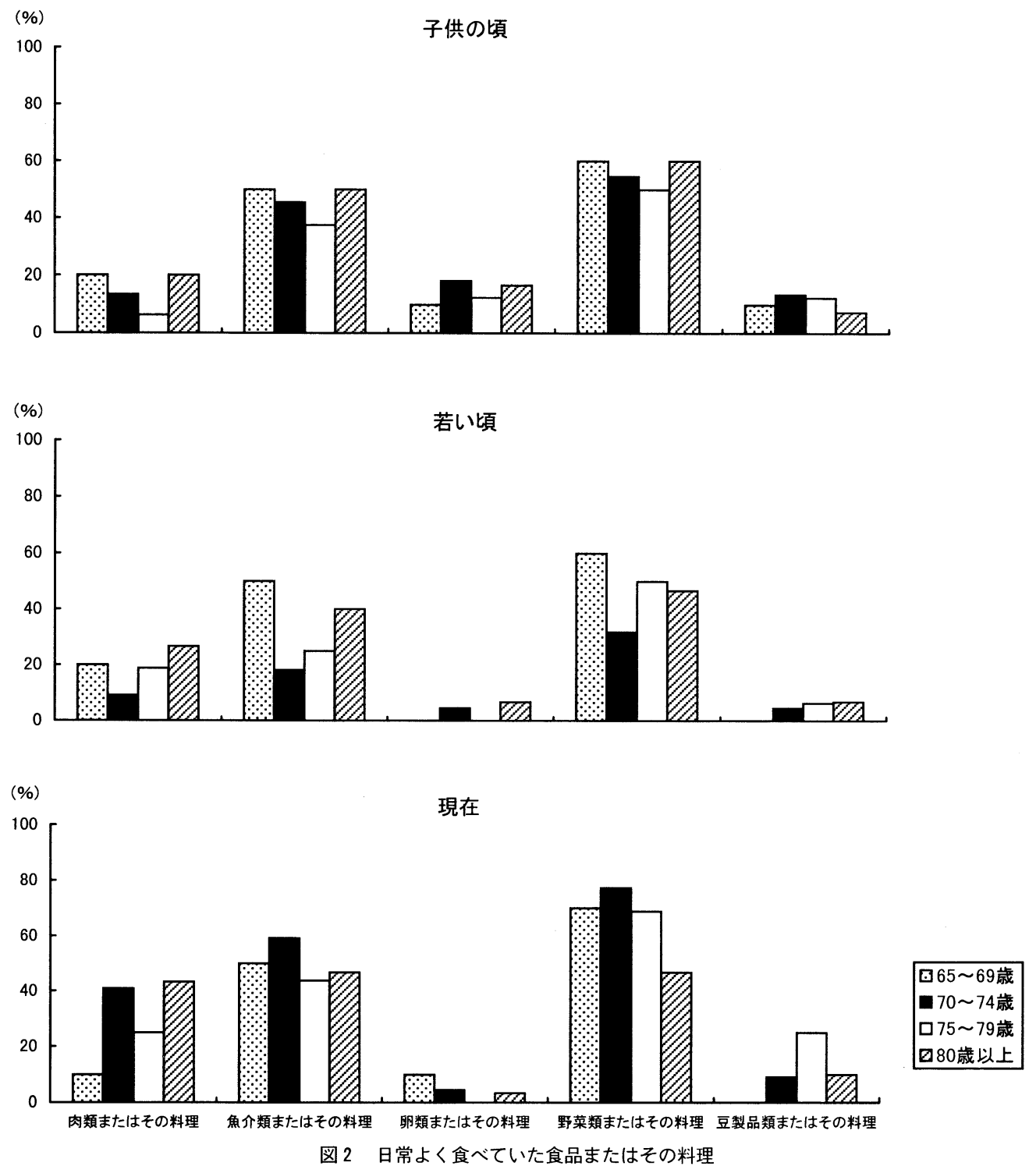

の食生活はかなり悪い状態であったと言える.

75 79歳:「子供の頃」と「若い頃」の雑穀飯等の割 合は各々 $37.6 \%$ と $56.3 \%$ であり,幼少期から青年期に至 るまでの長い期間に渡って貧しい食生活を送っていたこ とがわかった。

80歳以上：食糧事情が悪かったと思われる70〜 74歳の 「若い頃」および75～79歳の「子供の頃」と「若い頃」 と比較して，雑穀飯等を主食とした割合が，「子供の頃」 と「若い頃」の両時期ともにそれほど多くはなく，反対 に白米を主食とした割合は多かった．このことより，80
歳以上の者の食生活は, 最も栄養を必要とする青年期ま でにおいては 4 グループ中最も恵まれていたと思われ る.

「現在」の主食は, 年齢階級に関係なく 9 割以上の者 が白米と回答した。 また「現在」，パンを主食としてい る者の割合はどの年齢階級においても 5 割を超えている が，その中でも 80 歳以上の者は $76.7 \%$ という多い割合で パン食を食べていることがわかった。 


\section{4）副食に見る「子供の頃」と「若い頃」と「現在」 の食生活}

三つの時期の各々において日常よく食べていた食材を たは料理を自由に記述してもらった，それらを「肉類ま たはその料理」,「魚介類またはその料理」,「卵類または その料理」「「野菜類またはその料理」および「豆製品 類またはその料理」の五つの食品・料理群に分類し, 各 々を食していた割合を求めた。すなわち, 五つの食品・ 料理群それぞれにおいて, 各群に属する食材または料理 を記述した者の人数を各年龄階級の総人数で除した.

結果を図 2 に示した. なお,ここで言う野菜とは葉菜, 茎菜, 果菜, 根菜, 芋類, 豆類を指すものとした.

「子供の頃」と「若い頃」の二つの時期について見る と，どの年齢階級においても最もよく食されていた副食 は,「野菜類をたはその料理」であった。また, 動物性 の食品・料理群である「肉類をたはその料理」「魚介類 またはその料理」および「卵類をたはその料理」の中 では「魚介類またはとの料理」の摄取が最も多かった。 これは “魚, 肉, 鷄卵, 牛乳の動物性食品の消費量は大 正中期に増加し始め, 大正末期には大正初期の 2 倍に近 づいたがその中でも魚の消費量が際立って大きかった” という井上の調查報告6) と同様の傾向を示している. し かし，その「魚介類をたはその料理」の摂取も，食糧事 情の悪かった第二次世界大戦中および大戦直後の混乱期 と一致する70〜74歳と75７9歳の両グループの「若い頃」 には激隇している，また注目すべき点は，75～79歳のグ ループの「子供の頃」における「肉類またはその料理」 と「魚介類またはその料理」を食していた割合が同時期 の他のグループよりも少ないことであり, 時代的背景か ら見ると大戦前の食糧事情の比較的安定していたと思わ れる時期に該当するにもかかわらず, 貧しい食生活を送 っていたと考えられることである.なおこの傾向は, 前 述の主食によって食生活を考察した際にも同様に見られ た.

一方，80歳以上のグループにおける三つの動物性の食 品・料理群の摂取割合は, 「子供の頃」「若い頃」ともに, 他のグループよりも多い傾向が見られ，その中でも「肉 類またはその料理」の摂取割合は最も多かった。これは， 文献7によると “大正時代は明治時代に取り入れられた 西洋の食品や料理を日本型の食生活の中に吸収, 同化し た時期であり, 大正 $7 \sim 10$ 年頃に和洋折衷料理が日常化 されたとされている”が，80歳以上のグループの「子供 の頃」がこの時期に該当すること，また，このグループ の「子供の頃」および「若い頃」の大半が大戦前の食糧
事情の安定した時期に当たることがその一因であると考 えられる。

「現在」, 日常よく食されている副食については次の 三つの特徵的な結果が得られた.

まず第一に，「肉類またはその料理」における年齢階 級の最も低い $65 \sim 69$ 歳のグループの摂取割合が， $70 \sim 74$ 歳および80歳以上の両グループの摂取割合と比較して著 しく少なかったことである。この結果は，これまでの調 査で数多くなされてきた “加齢に伴い, 肉類の摂取割合 が低下する”との報告とは異なる．しかし，須山1 は， これまでの高齢者の食習慣に関する研究の多くは横断研 究であり,この方法では, 加齢効果とコホート効果を分 離できないために年齢皆級別の差を直接加齢変化として とらえ, その変化を著しく誇張してしまう危険性を述べ ている. そして, 須山の行った縦断研究に抢ける動物性 食品の摂取頻度の調査の結果では, 加齢による摂取頻度 の低下はほとんど見られず, 横ばい, もしくは増加傾向 を認めたと報告されている、したがって，年㱓階級の低 いグループに「肉類またはその料理」の摂取割合が少な い傾向が見られたという本調查結果は正しいものと考え られる。

第二に, 75〜79歳のグループの「肉類をたはその料理」 の拱取割合に少ない傾向が見られたが，このグループの 特徵として全体的に動物性食品の摂取割合が少ない傾向 にあること, しかし, その一方で植物性たんぱく質の供 給源である「豆製品類またはその料理」の摂取割合が他 のグループと比較して著しく多いことが挙げられる.こ れには, 本調査でわかったこのグループのみに特徵的に 見られた, 幼少期から青年期をでという非常に長期間に 渡り培われてきた質素な食生活の経験が関係しているの ではないかと考えられる.

第三に「卵類をたはその料理」については, 現在にお ける動物性食品の中では栄養価に優れ, 低価格で常備し やすく調理方法も比較的簡単であるにもかかわらず，ど の年齢階級においても摄取する割合が少なかったことが 挙げられる. 近年, 卵の優れた栄養面よりもコレステロ 一ル含量が高いことが取り上げられ, 動脈硬化や血栓を 心配する傾向が見られるが，その影響も反映されている と推察される.

なお，70〜74歳のグループについては明らかな特徵が 見られなかったが,この理由の一つとして, 過去の食生 活の中でも墸好を確立するのに大きな影響を与えると思 われる「子供の頃」の食生活が安定していたことが考え られる。 


\section{（3）現在の食習慣と生活習慣}

\section{1）現在の食習慣}

現在における 8 種の食品 (肉類, 魚介類, 卵, 野菜類, 果物, 牛乳, パン, 味噌汁）の摂取頻度を尋ね， 3 段階 尺度で得点化する方法を用いて評価を行った.すなわち， 「ほぼ毎日食べる」を 3 点, 「週 3 回以上食べる」を 2 点,「週 1,2 回食べる」を 1 点とし，「ほとんど食べな い」を 0 点とした.そして，これらの摂取頻度を得点化 したものの性別, 年齢階級別の平均值と標準偏差を求め, $\mathrm{t}$ 検定により有意差検定を行った. また，上記の食品の うち, 肉類, 魚介類, 野菜類, 果物, および牛乳につい ては合わせて嗜好も尋ね, 「好き」を 5 点, 「どちらかと いえば好き」を 4 点,「普通」を 3 点,「どちらかといえ ば嫌い」を 2 点，「嫌い」を 1 点とする 5 段階尺度の評 点法で捉え, 性別, 年㱓階級別の平均值と標準偏差を求 め, $\mathrm{t}$ 検定により有意差検定を行った.

結果を表 6-1, 表 6-2 拈よび表 7-1, 表 7-2に示 した.

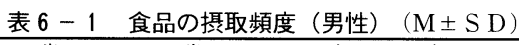

\begin{tabular}{|c|c|c|c|c|}
\hline & $\begin{array}{c}65 \sim 69 \text { 歳 } \\
\mathrm{n}=1\end{array}$ & $\begin{array}{c}70 \sim 74 \text { 歳 } \\
n=5(1) \text { 洋:2 }\end{array}$ & $\begin{array}{c}75 \sim 79 \text { 歳 } \\
\mathrm{n}=5\end{array}$ & $\begin{array}{c}80 \text { 歳以上 } \\
n=6\end{array}$ \\
\hline & & & \multicolumn{2}{|c|}{$* *$} \\
\hline 肉 類 & 一淮:1 & $1.40 \pm 0.55$ & $0.80 \pm 0.45$ & $2.33 \pm 0.82$ \\
\hline 魚介類 & - & $2.40 \pm 0.89$ & $1.80 \pm 1.10$ & $2.00 \pm 0.89$ \\
\hline 卵 & - & $1.40 \pm 1.14$ & $1.00 \pm 1.22$ & $1.83 \pm 0.75$ \\
\hline 野菜類 & - & $3.00 \pm 0.00$ & $2.60 \pm 0.55$ & $2.83 \pm 0.41$ \\
\hline 果 物 & - & $3.00 \pm 0.00$ & $1.60 \pm 1.52$ & $2.50 \pm 0.84$ \\
\hline 牛 乳 & - & $2.40 \pm 1.34$ & $\stackrel{*}{*}{ }^{*}{ }^{*}$ & $2.33 \pm 1.03$ \\
\hline パン & - & $2.00 \pm 1.41$ & $0.80 \pm 1.30$ & $2.00 \pm 1.26$ \\
\hline 味噌汁 & - & $2.80 \pm 0.45$ & $2.40 \pm 0.89$ & $2.00 \pm 1.26$ \\
\hline
\end{tabular}

注1）サンプル数が少ないため 注2）病歴ありの者の人数 ** $p<0.01$

\begin{tabular}{|c|c|c|c|}
\hline 表 7 & 1 食品の & 輓好（男性） & $(\mathrm{M} \pm \mathrm{S} D$ \\
\hline $\begin{array}{c}65 \sim 69 \text { 歳 } \\
n=1\end{array}$ & $\begin{array}{c}70 \sim 74 \text { 歳 } \\
n=5(1) \text { 注2 }\end{array}$ & $\begin{array}{c}75 \sim 79 \text { 歳 } \\
n=5\end{array}$ & $\begin{array}{c}80 \text { 歳以上 } \\
n=6\end{array}$ \\
\hline
\end{tabular}

肉類—泣 $14.20 \pm 0.84 \quad 3.20 \pm 1.64 \quad 4.67 \pm 0.82$

魚介類 一 $\quad 4.40 \pm 0.89 \quad 4.40 \pm 0.89 \quad 3.67 \pm 1.75$

野菜類 - $\quad 4.00 \pm 1.00 \quad 4.40 \pm 0.55 \quad 4.83 \pm 0.41$

$\begin{array}{llll}\text { 果 物 }-5.00 \pm 0.00 & * 6.60 \pm 1.14 & 4.50 \pm 1.22\end{array}$

牛乳 - $\quad 3.80 \pm 1.79 \quad 2.40 \pm 1.52 \quad 4.50 \pm 0.84$ 注1）サンプル数が少ないため 注2) 病歴ありの者の人数 $* \mathrm{p}<0.05$
なお，家族形態が食品摂取頻度に及ぼす影響が考えら れるが以下のように解釈し, 結果の分析を進めた. 池田 $5^{8)}$ は, 男女別に, 独居, 夫婦のみ, 2 世代, 3 世代以 上の四つの世帯形態別にバランススコア (12種類の食品 群を偏りなくとっているかを評価するスコア）を求め, 比較を行った. その結果, 独居の男性のスコアは統計学 的に有意に低く，女性については世帯形態によるスコア の差は認められなかったと報告している.しかし, 本調 査では表 1 より, 男性に抢ける独居の割合はどの年歯階 級においても0\%であったので家族形態による食品摂取 頻度への影響はないものと考えた. また, 本調査対象者 の主な居住地域である京都市と倉敷市との地理的条件を 比較すると, 倉敷市の方が海に近いために魚介類を食べ る機会に恵まれていると思われたため, 地域別, 性別, 年齢階級別に肉類と魚介類の摂取頻度と嗜好について比 較, 検討を行った，その結果, 近年のめざましく発達し

\begin{tabular}{cccc}
\multicolumn{2}{c}{ 表 $6-2$} & 食品の摂取頻度（女性） & $(\mathrm{M} \pm \mathrm{S} \mathrm{D})$ \\
\hline $65 \sim 69$ 歳 & $70 \sim 74$ 歳 & $75 \sim 79$ 歳 & 80 歳以上 \\
$n=8(1)^{n:}$ & $n=15(1)$ & $n=9(2)$ & $n=22(2)$ \\
\hline
\end{tabular}

肉 類 $1.13 \pm 0.64 \quad 1.53 \pm 0.74 \quad 1.38 \pm 0.52 \quad 1.09 \pm 0.81$

魚介類 $2.38 \pm 0.52 \quad 2.07 \pm 0.70 \quad 2.00 \pm 0.50 \quad 2.05 \pm 0.90$

卵 $1.63 \pm 0.742 .00 \pm 1.00 \quad 1.89 \pm 1.05 \quad 1.73 \pm 0.98$

野菜類 $2.88 \pm 0.35 \quad 3.00 \pm 0.00 \quad 3.00 \pm 0.00 \quad 2.91 \pm 0.29$

果 物 $2.50 \pm 0.76 \quad 2.60 \pm 0.63 \quad 2.67 \pm 0.71 \quad 2.73 \pm 0.46$

牛 乳 $2.63 \pm 0.52 \quad 2.00 \pm 1.25 \quad 1.78 \pm 1.20 \quad 2.14 \pm 1.36$

パン $2.25 \pm 1.16 \quad 2.14 \pm 1.24 \quad 2.33 \pm 0.71 \quad 2.41 \pm 1.05$ $\begin{array}{llll}\text { 味噌汁 } 2.13 \pm 1.13 & 2.60 \pm 0.63 & 2.89 \pm 0.33 & 1.86 \pm 0.89\end{array}$

注)病歴ありの者の人数

$* * p<0.01 \quad * * * p<0.001$

\begin{tabular}{cccc}
\multicolumn{2}{c}{ 表 $7-2$} & 食品の嗜好（女性） & $(\mathrm{M} \pm \mathrm{S} \mathrm{D})$ \\
\hline $65 \sim 69$ 歳 & $70 \sim 74$ 歳 & $75 \sim 79$ 歳 & 80 歳以上 \\
$n=8(1)^{\text {if: }}$ & $n=15(1)$ & $n=9(2)$ & $n=22(2)$ \\
\hline
\end{tabular}

肉 類 $3.88 \pm 0.834 .00 \pm 0.93 \quad 3.89 \pm 0.93 \quad 3.50 \pm 1.37$

魚介類 $4.63 \pm 0.74 \quad 4.53 \pm 0.83 \quad 4.56 \pm 0.88 \quad 4.09 \pm 1.15$

野菜類 $4.13 \pm 1.36 \quad 4.80 \pm 0.41 \quad 4.89 \pm 0.33 \quad 4.50 \pm 0.74$

果 物 $4.63 \pm 0.74 \quad 4.80 \pm 0.41 \quad 4.78 \pm 0.67 \quad 4.55 \pm 0.80$

牛 乳 $3.88 \pm 1.64 \quad 3.93 \pm 1.22 \quad 3.00 \pm 1.60 \quad 3.57 \pm 1.57$ 注) 病歴ありの者の人数 
表 81 日 3 食における主食のパターン (\%, 複数回答)

\begin{tabular}{|c|c|c|c|c|c|c|c|c|}
\hline & \multicolumn{2}{|c|}{ 65〜69歳 } & \multicolumn{2}{|c|}{$70 \sim 74$ 歳 } & \multicolumn{2}{|c|}{ 75〜79歳 } & \multicolumn{2}{|c|}{80 歳以上 } \\
\hline & 男性 & 女性 & 男性 & 女性 & 男性 & 女性 & 男性 & 女性 \\
\hline 飯＋飯＋飯 & -it & 22.2 & 50.0 & 31.3 & 60.0 & 18.2 & 16.7 & 16.7 \\
\hline 飯+パン+飯 & - & 0 & 0 & 12.5 & 20.0 & 27.3 & 0 & 9.5 \\
\hline パン+飯＋飯 & - & 44.4 & 50.0 & 43.8 & 0 & 18.2 & 33.3 & 42.9 \\
\hline パン+パン+飯 & - & 0 & 0 & 0 & 0 & 0 & 16.7 & 4.8 \\
\hline パン+めん+飯 & - & 22.2 & 0 & 12.5 & 20.0 & 18.2 & 33.3 & 42.9 \\
\hline 飯＋めん＋飯 & - & 22.2 & 0 & 18.8 & 0 & 36.4 & 16.7 & 4.2 \\
\hline パン+飯 +めん & - & 0 & 0 & 0 & 0 & 0 & 0 & 0 \\
\hline その他 & - & 11.1 & 0 & 6.3 & 0 & 0 & 16.7 & 0 \\
\hline
\end{tabular}

注)サンプル数が少ないため

た流通形態の影響のためか地域による差は特に認められ なかった。したがって, 本調査では食に関する地域差は ないものと考えた.

まず，男性についてであるが，75〜79歳のグループに おいて味噌汁を除く 7 食品の摂取頻度が他のグループと 比較して低い傾向が見られ，中でも肉類および牛乳の摂 取頻度については著しく低く，有意差が認められた．表 $7-1$ より, 肉類抢よび牛乳の嗜好が $75 \sim 79$ 歳のグルー プでは他のグループと比較して低い傾向が見られること がわかったことから，このグループにおける肉類抢よび 牛乳の摂取頻度には嗜好が関係しているものと考えられ る. また, 80 歳以上のグループの味増汁の摂取頻度が他 のグループよりも低い傾向にあった．女性については， 肉類, 魚介類, 卵, 野菜類, および果物の摂取頻度につ いては年齢階級間に特に差は認められなかった.しかし， 男性と同様に75〜79歳のグループにおける牛乳の摂取頻 度と, 80 歳以上のグループの味噌汁の摂取頻度について は各々他のグループよりも低い傾向が見られ，味噌汁に ついては70〜74歳および75〜79歳のグループとの間に有 意差が認められた．75〜 79歳のグループにおける牛乳の 嗜好が, 表 7 - 2 において他のグループと比較して低い 傾向が見られたことから，このグループにおける牛乳の 摂取頻度にも嗜好が関係しているものと考えられる。

また, 男女ともに80歳以上のグループにおいて味増汁 の摂取頻度が他のグループよりも低い傾向が見られた理 由については次のようなことが挙げられる。一つには, 本調査で先に得られた「パンを主食としている者の割合 は，80歳以上のグループに扔いて最も多かった」という 結果が，80歳以上のグループにおける米飯を主食として いる者の割合が他のグループよりも少ないことを示唆し ていること, また, 味噌汁は主に主食が米飯の時に供さ れる場合が多いことから, 主食として米飯を食べる頻度 が他のグループよりも少ないことが関係しているのでは ないかと考えられる．また，高齢化とともに起こる血圧
の上昇によって引き起こされる脸出血や狭心症, 動脈硬 化などの生活習慣病に対する食生活における予防として 塩分を控えめにすることが大切である ${ }^{9)}$ との認識が近年 では広くなされているために, 塩分の多い調味料の一つ である味噌を用いた味噌汁の摂取が，最も血圧の上昇し やすい年齢階級と思われる 80 歳以上のグループにおいて は特に意識的に控えられているのではないかとも考えら れる.

次に筆者は，表 6-1 および表 6- 2 において，男女と もに最も年齢階級の高い 80 歳以上のグループにおけるパ ンの摂取頻度が他のグループよりも高い傾向が見られた ことに注目し, 現在の 1 日 3 食における主食のパターン を性別, 年齢階級別に見ることにした. 主食パターンは, 「朝食十昼食十夕食」で表し, 吉田ら ${ }^{10)}$ の調査を参考に し, 「飯 + 飯 + 飯」,「飯 +パン + 飯」,「パン+飯+飯」, 「パン+パン+飯」,「パン+めん+飯」,「飯+めん+飯」, および「パン+飯めん」の七つのパターンを想定した. なお，1人が二つまたは三つのパターンを持つ者もいた ため複数回答となっている.

結果を表 8 に示した.

1987年に報告された60歳代から80歳代の男女を対象に した吉田ら ${ }^{10)}$ の調査結果では, “3 食とも飯” は男女平 均 $80.7 \%$ であり, 年齢の高い部分には米の愛着に変化が なかったとあるが，その12年後に行った本調査における 「飯+飯+飯」のパターンは男女合わせて $25.6 \%$ しか見 られなかった. 近年, 若年層における米食離れが問題視 されているが, 本調査によって高龄者においても同様の 傾向が見られることが明らかになった.

また，80歳以上のグループにおいては他のグループよ りも「パン+めん+飯」のパターンを持つ者が著しく多 かった.このパターンは米飯を 1 日のうちに 1 食しか食 べないことを示しており，80歳以上のグループにおける 米飯の摂取頻度が他のグループよりも低いことがわかっ た.しかしその一方, このグループにおいては「パン+ 
表 9 牛乳を飲む習慣を持つ者の割合 $(\%)$

\begin{tabular}{lcc}
\hline & 男 性 & 女 性 \\
\cline { 3 - 4 } & $\mathrm{n}=18$ & $\mathrm{n}=60$ \\
\hline $65 \sim 69$ 歳 & $0(0)$ & $44.4(33.3)$ \\
$70 \sim 74$ 歳 & $50.0(50.0)$ & $56.3(43.8)$ \\
$75 \sim 79$ 歳 & $0(0)$ & $36.4(27.3)$ \\
80 歳以上 & $66.7(66.7)$ & $50.0(41.7)$
\end{tabular}

( )内牛乳を10年間以上飲んでいる者の割合

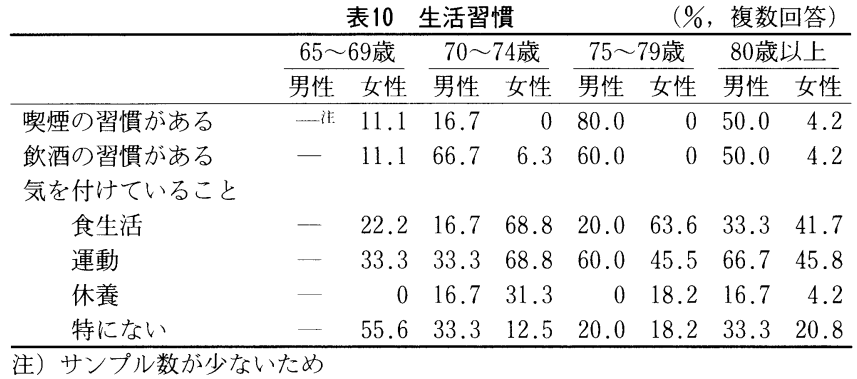

に行った集計結果を表 9 に示した。なお（）内の数 值は，牛乳を 10 年以上飲んでいる者の割合である.

これまで述べてきた調査結果を反映するように，男女 ともに 75〜 79歳のグループにおける牛乳を飲む習慣とし ている者の割合は著しく少なかった。

\section{2）現在の生活習慣}

これまでの喫煙および飲酒の習慣の有無および健康で いるために気をつけている生活習慣について自由記述し てもらった結果を食生活, 運動, 休養, 特になしの 4 項 目に分類して集計した結果を性別，年路階級別に表10に 示した.

生活習慣については，年龃階級間における差は特に認 められなかったが，性差が認められた，すなわち，生活 習慣で気をつけていることの内容として食生活に関する 事柄を挙げた者の割合は女性に多く，男性においては食 生活よりも運動に関する事柄を挙げた者の割合の方が多 かった，また，男性の方が，女性と比較すると契煙や飲 酒の習慣を持つ者の割合が多く，生活習慣で気をつけて いることは特にないと回答した者の割合も多かった，現 在，98年簡易生命表によると男女の平均寿命差は6.85歳 であるが，これには本調査で明らかとなったような食生 活をも含めた生活習慣に対する男女間の意識の差が一因 となっている可能性が考えられる.

\section{要 約}

65歳以上の高齢者78名を対象とし,「子供の頃」「「若 い頃」, および「現在」の食生活に関する調査を実施し た、筆者は，対象者の年㱓によって「子供の頃」や「若 い頃」に体験した食生活が異なることに注目し，このこ とが現在の食習慣に及ぼす影響を考慮するために，65～ 69歳, $70 \sim 74$ 歳, $75 \sim 79$ 歳, および 80 歳以上の四つの年 齢階級に分類した。各年齢階級の現在の食習慣の特徵を 考察し, 以下の結果を得た.

65〜69歳:「子供の頃」は恵をれた食生活であったと 
は言えないが,「若い頃」の食生活は安定していた.「現 在」の食習慣の特徵としては, 年齢皆級が最も低いにも かかわらず，肉類あるいはその料理の摄取割合や摄取頻 度が他の年龄階級よりも低い傾向が見られることが挙げ られる。

$70 \sim 74$ 歳：「子供の頃」の食生活は比較的安定してい たが，「若い頃」の食生活はかなり貧しかった。「現在」 の食習慣に明らかな特徵が見られなかったが，この理由 の一つとして，過去の食生活の中でも嗜好を確立するの に大きな影響を与えると思われる「子供の頃」の食生活 が安定していたことが考えられる。

75 79歳：「子供の頃」と「若い頃」の両時期に渡っ て食生活はかなり貧しかった。「現在」の食習慣の特徵 として, 動物性食品の摂取割合が少ない傾向にあり，そ の中でも男性に打ける肉類の摂取頻度が著しく低いこと と, 男女ともに牛乳の摂取頻度が著しく低いことが挙げ られる.これらの要因として, 幼少期から青年期むでの 長期間に渡る筫困な食生活による莻好の偏りが考えられ る.

80 歳以上 : 「子供の頃」と「若い頃」の両時期ともに 食生活には恵をれており，他の年齢階級よりも動物性食 品の摄取割合が多く,中でも肉類の摂取割合が多かった. このような過去の食生活は, 年齢階級が最も高いにもか かわらず，肉類あるいはとの料理の摂取割合や摂取頻度 に高い傾向が見られるという「現在」の食習慣の特徵に 影響を及ぼしているとも考えられる．また，80歳以上の 「現在」の食習慣においては，パンを主食とする割合が 著しく多く,味増汁の摂取頻度が低い傾向が認められた。
これは飯を主食とし，その副食として味噌汁を供すると いう日本型食生活が最も高い年齢階級に扔いても変化し てきていると推察される．これらの結果は，本人の意志 のみではなく，80歳以上の高齢者が現在取り囲まれてい る環境が大きく影響しているものと思われる.

また，高秢者においても若年層と同様に米食離れの傾 向が見られることが明らかになったこと，身体に良い食 品として日常, 習慣的に牛乳を摂取している者の割合が 非常に多いこと，および食生活を含めた生活習慣に対す る意識の差に性差が見られることは注目すべきことであ る.

\section{参考文献}

1）須山靖男 : 調理科学, 32，1，67（1999）

2）田中平三監訳 : 食事調査のすべて一栄養疫学一, 第一出版, p.148 153 (1996)

3) 積田亨他編 : 老化の科学一21世紀への老化研究をめざして一, 東京化学同人, p.145 149（1994）

4）廣田才之 (代表) 編：公衆栄養学, 共立出版, p.22 24 (1994)

5）芦田淳：食生活と栄養，同文書院，p.25２8（1991）

6）井上兼雄 : 糧食研究, 101，1563（1934）

7）昭和女子大学食物学研究室: 近代日本食物史, 近代文化研究 所, p. 810 812 (1971)

8）池田順子, 浅野美登里, 木谷輝男, 永田久紀：栄盖誌, 49 , 5,257 (1991)

9）林淳三 : 高齢者の栄養と食生活, 建帛社, p. 110 112 (1997)

10）吉田繁子，若林敏子，出宮一徳：栄養誌， 45, 1，11 (1987)

11）笠松隆洋, 吉村典子, 森岡聖次, 橋本勉: 栄養誌, 53,3 , 175 (1995) 